\title{
Analysis of harbor porpoise gillnet bycatch, compliance, and enforcement trends in the US northwestern Atlantic, January 1999 to May 2010
}

\author{
Christopher D. Orphanides ${ }^{1, *}$, Debra L. Palka ${ }^{2}$ \\ ${ }^{1}$ NOAA National Marine Fisheries Service, Northeast Fisheries Science Center, 28 Tarzwell Drive, Narragansett, \\ Rhode Island 02882, USA \\ ${ }^{2}$ NOAA National Marine Fisheries Service, Northeast Fisheries Science Center, 166 Water Street, Woods Hole, \\ Massachusetts 02543, USA
}

\begin{abstract}
In 1999 the US National Marine Fisheries Service (NMFS) implemented regulations to limit harbor porpoise Phocoena phocoena incidental bycatch in US waters of the northwestern Atlantic. This effort was called the Harbor Porpoise Take Reduction Plan (HPTRP) and included a mixture of time-area closures, pinger and other gear modification requirements, a pinger training program, and outreach and education efforts. This paper focuses on the plan from January 1999 to May 2010 and examines trends in bycatch patterns, compliance with the plan, enforcement of the plan requirements, and changes in the primary fisheries involved in harbor porpoise bycatch. Over the course of the plan harbor porpoise bycatch dropped in the first few years, increased to unacceptable levels during the middle years, and moderated in the later years of the plan. Changes in fishing effort and distribution of key fisheries played a large role in decreasing the bycatch in much of the Mid-Atlantic and also in increasing bycatch in Southern New England and off the coast of New Jersey. The pattern in compliance levels had an inverse relationship with bycatch levels, with better compliance and lower bycatch in early and late years, though compliance was generally poor even when at its best. Enforcement of HPTRP regulations was not well documented, but, from available compliance data, it appears that what enforcement did occur was not sufficient to improve compliance. Given poor compliance with pinger requirements, these requirements have not resulted in the expected reduction in bycatch.
\end{abstract}

KEY WORDS: Porpoise - Bycatch · Gillnet · Pinger - Marine Mammal Management - Take Reduction Team

\section{INTRODUCTION}

Harbor porpoise Phocoena phocoena bycatch occurs in gillnets throughout the species' distribution in the boreal waters of the northern hemisphere (Gaskin 1984, Jefferson \& Curry 1994, Tregenza et al. 1997, Trippel et al. 1999, International Whaling Commission 2000, Berggren et al. 2002, Barlow \& Cameron 2003, Vinther \& Larsen 2004, Orphanides 2009). By- catch levels have been documented (e.g. Waring et al. 2011), and pingers (acoustic alarms) have been proven capable of limiting harbor porpoise bycatch (Kraus et al. 1997, Dawson et al. 2013 this Theme Section), though limited attention has been given to a comprehensive review of harbor porpoise management measures in a real world setting. The Harbor Porpoise Take Reduction Plan (HPTRP) along the northeastern United States (63 FR 66464, 2 Decem- 
ber 1998), which has been in place since 1999, provides a good opportunity for such a review. Modifications to the HPTRP were implemented in February of 2010 (75 FR 7383, 19 February 2010), so this paper focuses on the time period prior to these modifications.

Harbor porpoises are the smallest cetaceans in the North Atlantic, averaging roughly $1.5 \mathrm{~m}$ in length. Those located off the northeastern United States are the Gulf of Maine/Bay of Fundy stock. The abundance of this stock has fluctuated over time, but the most recent abundance estimate was about 89000 animals based on a 2006 line transect sighting survey (Waring et al. 2011). The distribution of this stock ranges from North Carolina to the Bay of Fundy and the Scotian shelf off Nova Scotia, Canada. This stock's distribution varies seasonally, which plays a large role in the seasonal bycatch of these animals (Table 1). In summer, harbor porpoises are concentrated in the northern Gulf of Maine and southern Bay of Fundy, away from the majority of US gillnets (see Fig. 1). During fall and spring, harbor porpoises are more widely dispersed, from Maine to New Jersey. During winter, specifically January through April, harbor porpoise distribution stretches as far south as North Carolina, though some harbor porpoises are still present in more northern waters (Orphanides 2009, Waring et al. 2011; see our Fig. 2). Although harbor porpoise distribution expands south in the colder months, there does not appear to be a distinct migratory corridor or coordinated migration, rather a seasonal shift in the peak distribution along with an expansion of their seasonal range, probably following their prey species. Harbor por-

Table 1. Phocoena phocoena. Northeast Fisheries Observer Program observed harbor porpoise bycatch from 1999 through May of 2010 by month and region. GOM: Gulf of Maine; SNE: Southern New England; WNJ: Waters off New Jersey; SMA: Southern Mid-Atlantic

\begin{tabular}{|lccccc|}
\hline Month & GOM & SNE & WNJ & SMA & Total \\
\hline Jan & 10 & 11 & 12 & 0 & 33 \\
Feb & 16 & 21 & 37 & 1 & 75 \\
Mar & 22 & 20 & 12 & 6 & 60 \\
Apr & 7 & 35 & 5 & 2 & 49 \\
May & 7 & 28 & 0 & 0 & 35 \\
Jun & 3 & 0 & 0 & 0 & 3 \\
Jul & 3 & 0 & 0 & 0 & 3 \\
Aug & 2 & 0 & 0 & 0 & 2 \\
Sep & 10 & 0 & 0 & 0 & 10 \\
Oct & 13 & 0 & 0 & 0 & 13 \\
Nov & 36 & 2 & 0 & 0 & 38 \\
Dec & 22 & 1 & 0 & 0 & 23 \\
Total & 151 & 118 & 66 & 9 & 344 \\
\hline
\end{tabular}

poises in the Northwest Atlantic tend to stay in the Gulf of Maine or on the continental shelf, although they have been observed on occasion in waters off the shelf break (Read \& Westgate 1997, Orphanides 2009, Waring et al. 2011).

Harbor porpoises have been caught in gillnets along the northeastern US coast since the 1880s (Collins 1886). However, it was not until nearly $100 \mathrm{yr}$ later that scientists began to be concerned about the high levels of harbor porpoise bycatch off the northeastern USA, particularly in the Gulf of Maine (Gaskin 1984, Read 2013 this Theme Section). A group of fishermen met informally with scientists, fishery managers, and representatives of non-governmental organizations to discuss this issue as far back as 1990. Then, in September of 1991, the Sierra Club Legal Defense Fund, on behalf of 13 other organizations, petitioned the National Marine Fisheries Service (NMFS) to list the Gulf of Maine/Bay of Fundy harbor porpoise stock as threatened under the Endangered Species Act (NMFS 1991). This compelled fishermen to explore ways to reduce harbor porpoise bycatch (Read 2013).

Formal meetings addressing this issue began in 1992 with a Marine Mammal Subgroup of the New England Fishery Management Council (Read 2013) and led to the exploration of several management and research measures. The Council employed timearea closures beginning in March of 1994 (Murray et al. 2000), and pinger experiments were conducted to evaluate the degree to which these devices could limit harbor porpoise bycatch (e.g. Kraus et al. 1997). The time-area closures established in the mid- to late 1990s reduced bycatch and served as a template for future management actions. Pinger experiments, particularly the Kraus et al. (1997) experiment, set the stage for pinger use in harbor porpoise management as it conclusively demonstrated a large (92\%) drop in harbor porpoise bycatch in nets equipped with pingers.

In 1994, the US government reauthorized the Marine Mammal Protection Act. This act aims to keep marine mammal stocks at their optimal sustainable population level. This is a population level at which a stock is as large as can be supported by the ecosystem and is also able to grow at its top rate when accounting for natural mortality. To accomplish this, the Marine Mammal Protection Act defined a threshold on human-related mortalities, termed the Potential Biological Removal (PBR) level. This level is designed so that if human-related mortality levels are kept at or below PBR, a stock can grow to, or be maintained at, its optimal sustainable population 
level. PBR is calculated using estimates of abundance and their coefficients of variance, measures of the reproductive capability of the stock, and the coefficient of variance of the estimate of human-related mortality. As these data are updated from year to year, PBR changes as well. In the case of cross-boundary stocks, such as harbor porpoise, the mortality level that is compared to PBR can include mortality in neighboring countries (such as Canada), provided that a mortality estimate for the neighboring country is available and the abundance estimate includes those animals that use the other country's waters.

The 1994 Marine Mammal Protection Act amendments also required the creation of Take Reduction Teams (TRTs) when fishing-induced mortality of a marine mammal stock is impacting the stock's ability to stay at its optimum sustainable population. A TRT includes various stakeholders, typically consisting of fishing industry representatives, federal agencies, state agencies, non-governmental environmental organizations, and independent scientists. If fishinginduced morality is greater than PBR (endangering a stock's ability to remain at its optimal sustainable population), a TRT is convened to develop a plan (a Take Reduction Plan, or TRP) that will reduce bycatch levels to below PBR within 6 mo of its implementation. This plan may consist of recommendations to NMFS on potential regulatory and non-regulatory measures to reduce bycatch levels, and it may also include recommendations for additional research. The long-term goal of these plans is to reduce marine mammal bycatch to insignificant levels approaching a zero rate, referred to as the zero mortality rate goal (ZMRG). This level was later defined as $10 \%$ of the PBR level (69 FR 43338, 20 July 2004).

In the case of these harbor porpoises, the work required by a TRT had already been started by the Marine Mammal Subgroup of the New England Fishery Management Council. So, after the TRT process was established in the 1994 Marine Mammal Protection Act amendments, TRTs continued the work of the New England Fishery Management Council. Two harbor porpoise TRTs were convened in 1996 and 1997 to reduce harbor porpoise bycatch because the bycatch estimated for 1995 (1503) far exceeded PBR (483). One TRT dealt with the Gulf of Maine and Southern New England gillnet fisheries, and the other dealt with the Mid-Atlantic gillnet fisheries. The Take Reduction Plans developed by these teams were then combined and published in 1998, although most measures became effective in January 1999 (63 FR 66464, 2 December 1998). In the Gulf of Maine and Southern New England waters, the HPTRP consisted of a mixture of time-area closures, pinger requirements, outreach and education efforts, and, in areas where pingers were required, a pinger training program (Fig. 1). Many of the measures included in the HPTRP were those developed earlier by the New England Fishery Management Council's efforts to reduce harbor porpoise bycatch. To obtain a more complete history on the development of harbor porpoise management in the Gulf of Maine from 1982 through 1999 consult Read (2013).

The Mid-Atlantic portion of the HPTRP did not include pinger requirements, but instead relied on a mixture of time-area closures and gear modification requirements (Table 2, Fig. 2) in combination with outreach and education. The gear requirements varied by area and mesh size because the bycatch varied by area and mesh size. The gear requirements included restrictions on float line length, twine size, tie-downs, net size, net length, nets per vessel, and nets on a string (Table 2). Because the Mid-Atlantic TRT recognized the high bycatch rates in gillnets tar-

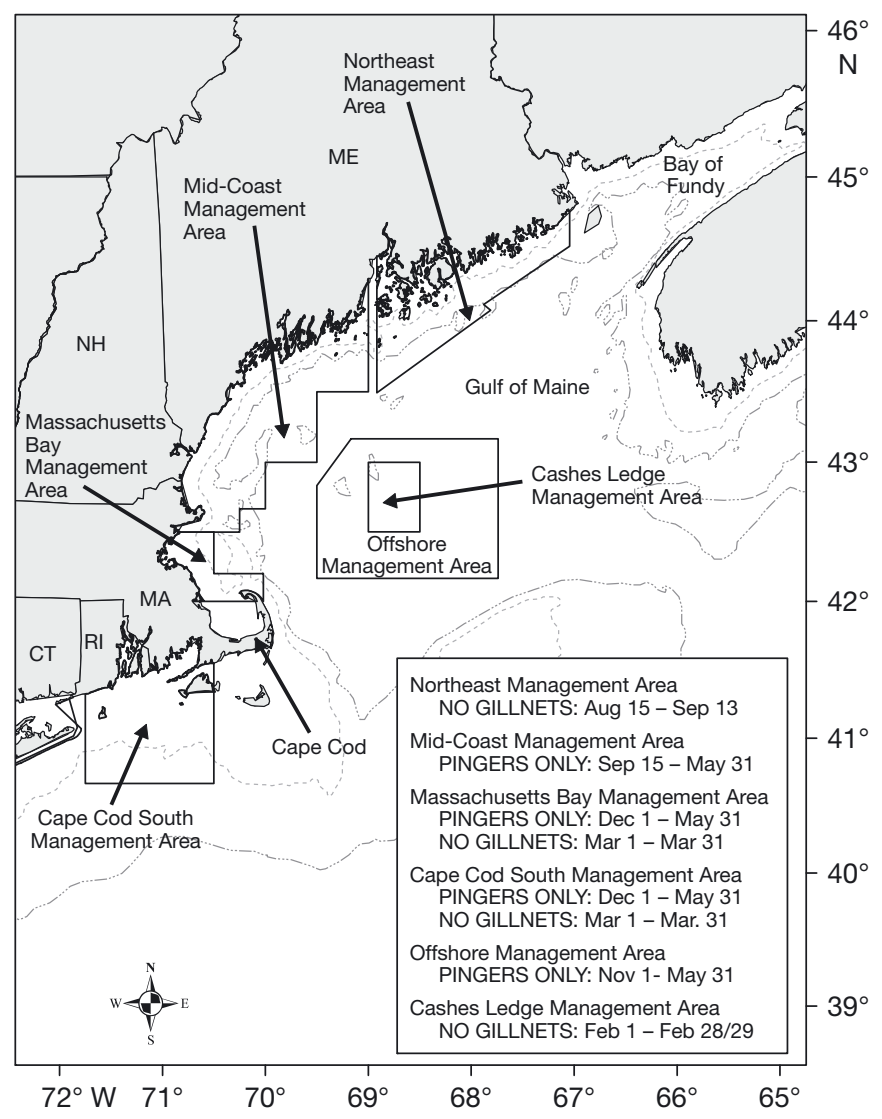

Fig. 1. Harbor Porpoise Take Reduction Plan management areas for New England, USA. The 50 and $100 \mathrm{~m}$ depth contours are also shown 
Table 2. Harbor Porpoise Take Reduction Plan (HPTRP) management measures for large and small mesh nets in the Mid-Atlantic gillnet fishery that were in effect from June 2009 to February 2010. Note: a net tagging program for both large and small mesh nets was specified in the HPTRP, but was not implemented. NJ: New Jersey (USA)

\begin{tabular}{|c|c|}
\hline \multicolumn{2}{|c|}{ Large mesh gillnets ( 7 to 18 inches $[17.8$ to $45.7 \mathrm{~cm}]$ ) } \\
\hline Mudhole & $\leq 3900 \mathrm{ft}(1189 \mathrm{~m})$ \\
\hline Waters off NJ (excluding Mudhole) & $\leq 4800 \mathrm{ft}(1643 \mathrm{~m})$ \\
\hline Southern Mid-Atlantic & $\leq 3900 \mathrm{ft}(1189 \mathrm{~m})$ \\
\hline Twine size & $\geq 0.90 \mathrm{~mm}$ \\
\hline Tie downs & $\begin{array}{l}\text { Required; spaced } \leq 15 \mathrm{ft} \text { apart } \\
\text { along floatline; } \leq 48 \text { inches in length }\end{array}$ \\
\hline Net number per vessel & $\leq 80$ nets \\
\hline Net size & $\leq 300 \mathrm{ft}(91.4 \mathrm{~m})$ \\
\hline \multicolumn{2}{|l|}{ Number of nets within a net string } \\
\hline Mudhole & $\leq 13$ nets \\
\hline Waters off NJ (excluding Mudhole) & $\leq 16$ nets \\
\hline Southern Mid-Atlantic & $\leq 13$ nets \\
\hline \multicolumn{2}{|l|}{ Time-Area closures } \\
\hline Waters off NJ (including Mudhole) & Closed from 1-20 Apr \\
\hline Mudhole & losed from 15 Feb-15 Mar, $1-20$ Apr \\
\hline Southern Mid-Atlantic & Closed from 15 Feb-15 Mar \\
\hline \multicolumn{2}{|l|}{ Gear modification requirements } \\
\hline Waters off NJ (excluding Mudhole) & 1 Jan-30 Mar and 21-30 Apr \\
\hline Mudhole & an-14 Feb; $16-31$ Mar; and 21-30 Apr \\
\hline Southern Mid-Atlantic & $1-14$ Feb and 16 Mar-30 Apr \\
\hline \multicolumn{2}{|c|}{ Small mesh gillnets $(>5$ to $<7$ inches $[>12.7$ to $<17.8 \mathrm{~cm}])$} \\
\hline \multicolumn{2}{|l|}{ Float line length } \\
\hline Waters off NJ (including Mudhole) & $\leq 3000 \mathrm{ft}(914 \mathrm{~m})$ \\
\hline Southern Mid-Atlantic & $\leq 2118 \mathrm{ft}(646 \mathrm{~m})$ \\
\hline Twine size & $\geq 0.81 \mathrm{~mm}$ \\
\hline Tie downs & Prohibited \\
\hline Net number per vessel & $\leq 45$ nets \\
\hline Net size & $\leq 300 \mathrm{ft}(91.4 \mathrm{~m})$ \\
\hline \multicolumn{2}{|l|}{ Number of nets within a net string } \\
\hline Waters off NJ (including Mudhole) & $\leq 10$ nets \\
\hline Southern Mid-Atlantic & $\leq 7$ nets \\
\hline \multicolumn{2}{|l|}{ Time-Area closures } \\
\hline Mudhole & Closed from 15 Feb-15 Mar \\
\hline \multicolumn{2}{|l|}{ Gear modification requirements } \\
\hline Waters off NJ (excluding Mudhole) & 1 Jan-30 Apr \\
\hline Mudhole & $1 \mathrm{Jan}-14$ Feb and 16 Mar-30 Apr \\
\hline Southern Mid-Atlantic & 1 Feb-30 Apr \\
\hline
\end{tabular}

geting monkfish Lophius americanus and spiny dogfish Squalus acanthias, the Mid-Atlantic gear restrictions of the HPRTP (Table 2) were designed to limit bycatch in these fisheries without limiting fishing (Mediation Institute 2000a). This was done by restricting allowable gear characteristics to those characteristics that successfully caught fish and also had low observed bycatch rates. It was envisioned that if fishing for these target species increased because the status of the fish stock improved, the target fish catches would increase, while the harbor porpoise bycatch would still be low because only gear with low bycatch rates would be allowed.
In 1989, the Northeast Fisheries Science Center (NEFSC) started an observer program that required fishers to take trained fisheries observers on board to collect data on fishing activities. These data are used to estimate annual bycatch and to monitor effectiveness of the HPTRP. From 1990 through 1997, the annual bycatch estimates in the combined New England and Mid-Atlantic gillnet fisheries fluctuated between 1200 and 2900 animals (Fig. 3) (Waring et al. 1997, 2000). This included an estimated 424 porpoises taken by Canadian gillnetters in the Bay of Fundy in 1993 (Trippel et al. 1996), although this take declined to $<100$ by the mid-1990s (Trippel et al. 1996, 1999, DFO 1998). After the implementation of the HPTRP, bycatch was reduced, but fluctuated over the course of the HPTRP.

In this paper we describe patterns in bycatch, compliance, enforcement, and fisheries affected by the HPTRP from 1999 to the spring of 2010, discuss the effectiveness of the HPTRP, and examine the HPTRP's successes and failures. Nearly all data presented in this report are available in other documents. However, to provide a complete picture of the trends during this entire time period, figures of monthly and regionally observed bycatch totals, some of which are partially available in other documents, are summarized here using Northeast Fisheries Observer Program data. To put the events related to the HPTRP into perspective, we first provide background information on the primary gillnet fisheries affected by the HPTRP and the fisheries management framework in effect at that time. Next, we discuss other issues chronologically as they occurred through the 1999 to 2010 time period, breaking the time up into early (1999 to 2001), middle (2002 to 2006), and late time periods (2007 to 2010), with a discussion of the 2007 and 2008 TRT meetings summarized between the middle and late time periods. The time periods are based largely on patterns in the annual bycatch estimates and the timing of the 2007 and 2008 TRT meetings. Each time period focuses on 3 main themes: (1) overall bycatch and abundance 
patterns, (2) compliance with the HPRTP, and (3) detailed descriptions of changes in bycatch patterns and associated changes in the fisheries involved. Then we discuss general issues related to enforce-

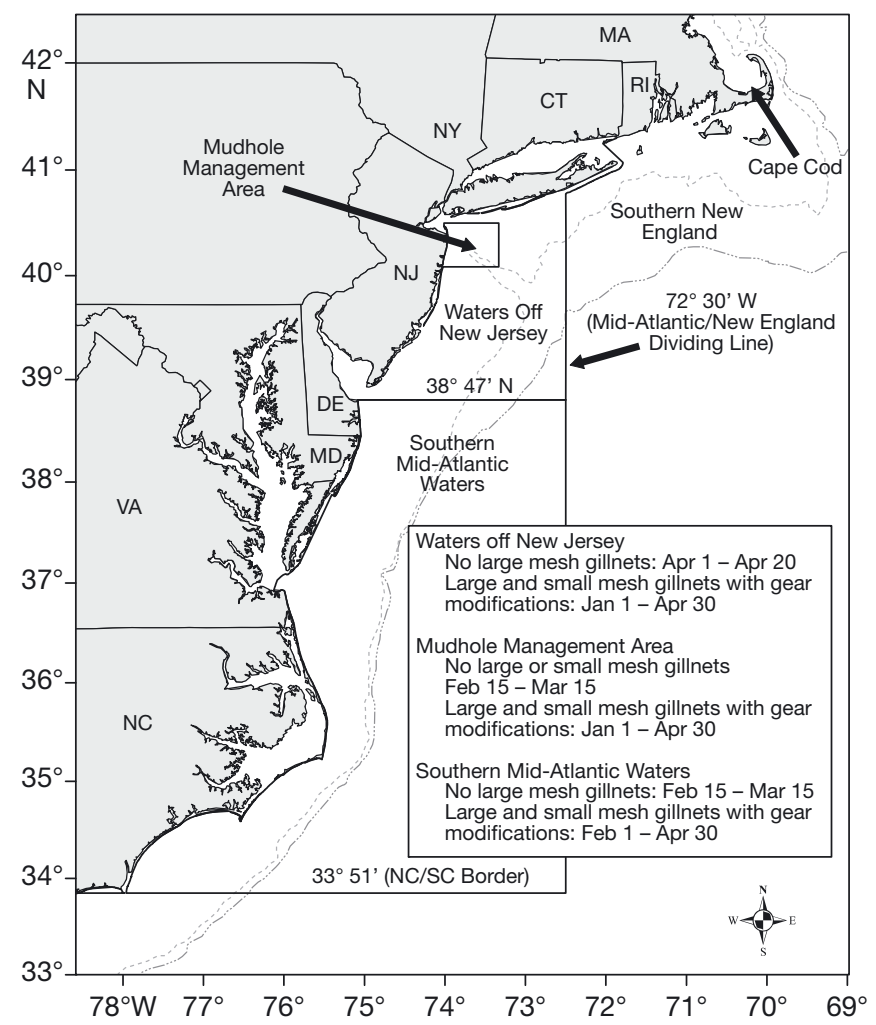

Fig. 2. Harbor Porpoise Take Reduction Plan management areas for the Mid-Atlantic. The 50 and $100 \mathrm{~m}$ depth contours are also shown

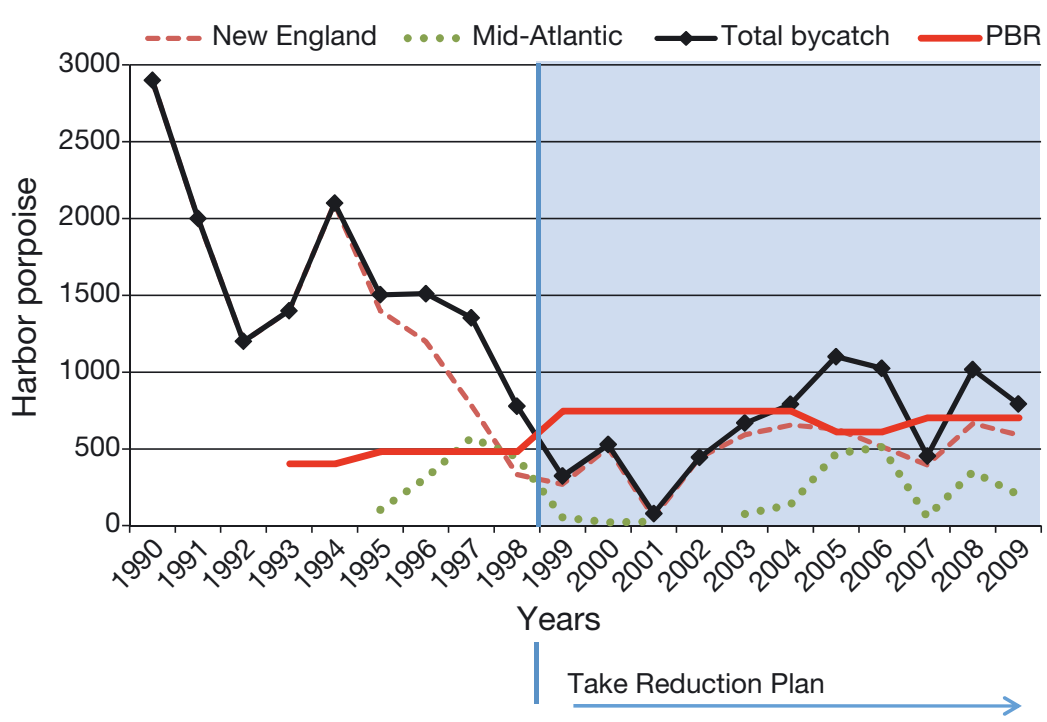

Fig. 3. Annual harbor porpoise Phocoena phocoena bycatch estimates in New England, the Mid-Atlantic, and the total bycatch combined from both regions, as compared to the Potential Biological Removal (PBR) ment and development of a pinger tester that is used by fishery observers. Lastly, we bring all these components together in a summary of the general trends. It is hoped that this paper will not only be informative to future harbor porpoise management in the northeastern USA, but also serve as a resource for others around the world that are developing harbor porpoise bycatch conservation measures.

\section{BACKGROUND}

\section{New England gillnet fisheries}

Gillnet fishing off the northeastern USA (US waters east of $72.5^{\circ}$ longitude; Fig. 1) is dominated by sink gillnets secured to the bottom with anchors. Gillnet strings are typically composed of 10 monofilament nets 1.5 to $4.6 \mathrm{~m} \mathrm{(5} \mathrm{to} 15 \mathrm{ft}$ ) in height and $91.4 \mathrm{~m}$ (300 ft) in length, for a total string length of approximately 914 m (3000 ft) (Palka et al. 2008, Orphanides 2011a). However, actual string length and number of nets varies by vessel and target species and typically ranges from 610 to $1219 \mathrm{~m} \mathrm{(2000} \mathrm{to} 4000 \mathrm{ft}$ ) (Palka et al. 2008). Fishermen most often let their nets soak 24 to $48 \mathrm{~h}$, though longer soak times are not uncommon for some target species. Species caught are determined largely by the size of the mesh. For example, $30.5 \mathrm{~cm}$ (12 in) stretched mesh nets are commonly used to target monkfish and sometimes winter skate Raja ocellata. Smaller meshes of 15.2 to $22.9 \mathrm{~cm}$ (6 to 9 inches) are commonly used to target a mixture of species collectively called 'groundfish' that are managed by the Northeast Multispecies Fishery Management Plan (FMP), though this mesh size is also used to target spiny dogfish. Chief among the groundfish target species is Atlantic cod Gadus morhua, though the groundfish assemblage managed under the Northeast Multispecies FMP also includes 14 other species: American plaice Hippoglossoides platessoides, Atlantic halibut Hippoglossus hippoglossus, Atlantic wolffish Anarhichas lupus, haddock Melanogrammus aeglefinus, ocean pout Macrozoarces americanus, offshore hake Merluccius albidus, pollock Pollachius virens, red hake Urophycis chuss, redfish Sebastes marinus, silver hake Merluccius bilinearis, white hake Urophycis tenuis, windowpane flounder Lophopsetta maculata, winter flounder Pseudopleuronectes ame- 
ricanus, witch flounder Glyptocephalus cynoglossus, and yellowtail flounder Limanda ferruginea. However, 3 of the species officially included in the management plan (offshore hake, red hake, and silver hake) are essentially treated as a separate small mesh FMP because they are caught in small mesh (typically 6.35 to $7.62 \mathrm{~cm}$ [2.5 to 3.0 inches]), whereas the other species are primarily caught in larger mesh (16.5 cm [6.5 inches] or larger). Also, Atlantic wolfish was only added to the FMP on 1 May 2010, and so was not part of the FMP for most of the period discussed in this paper.

Gillnet vessels in this region are typically small, owner-operated vessels (mean vessel length is about $12.19 \mathrm{~m}[40 \mathrm{ft}]_{;}$NMFS unpubl. data). These gillnet vessels are generally smaller than those used in the trawl fleet (Orphanides \& Magnusson 2007). The number of active permit holders in New England gillnet fisheries reported in marine mammal stock assessments varied from 361 in 2002 to 178 in 2009, though the number of active permit holders was not reported each year (Waring et al. 2007b, 2011). Gillnetters may hold permits for multiple fisheries and switch between different target species depending on management restrictions, season, market price, and other factors. In addition, these fishers are often able to switch from gillnetting to lobstering (using traps) or longlining without major changes to their vessels. Thus, it is difficult to discern how many vessels were fishing for a particular target species during a given year. The location of gillnet fishing in New England varies by season but can generally be divided into 2 regions: the Gulf of Maine and Southern New England (Fig. 4). In the Gulf of Maine much of the effort occurs off the coasts of Massachusetts, New Hampshire, and southern Maine, with limited effort in the middle of the Gulf of Maine or on Georges Bank. Southern New England groundfish effort is often along

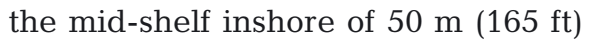
depth and east of Cape Cod, extending south along the Great South Channel where dogfish effort also occurs. Monkfish and skate effort in Southern New England occupies a larger area of the shelf extending south to the shelf break and also east of Cape Cod, but not as far south along the Great South Channel as groundfish effort.

\section{Mid-Atlantic gillnet fisheries}

Gillnet fishing effort in the Mid-Atlantic (west of $72.5^{\circ}$ longitude, and south to $33.85^{\circ}$ latitude; Fig. 2) consists of nets targeting a variety of species including monkfish, croaker Micropogonias undulates, weakfish Cynoscion regalis, striped bass Morone saxatilis, bluefish Pomatomus saltatrix, and spiny dogfish (Orphanides 2009). The active permit holders in the Mid-Atlantic gillnet fisheries varied from 230 in 2006 to 137 in 2009, though the numbers of active permit holders were not recorded in stock assessment reports prior to 2006 (Waring et al. 2007b, 2011). The nets fished in the Mid-Atlantic are mostly made of monofilament twine as in New England,

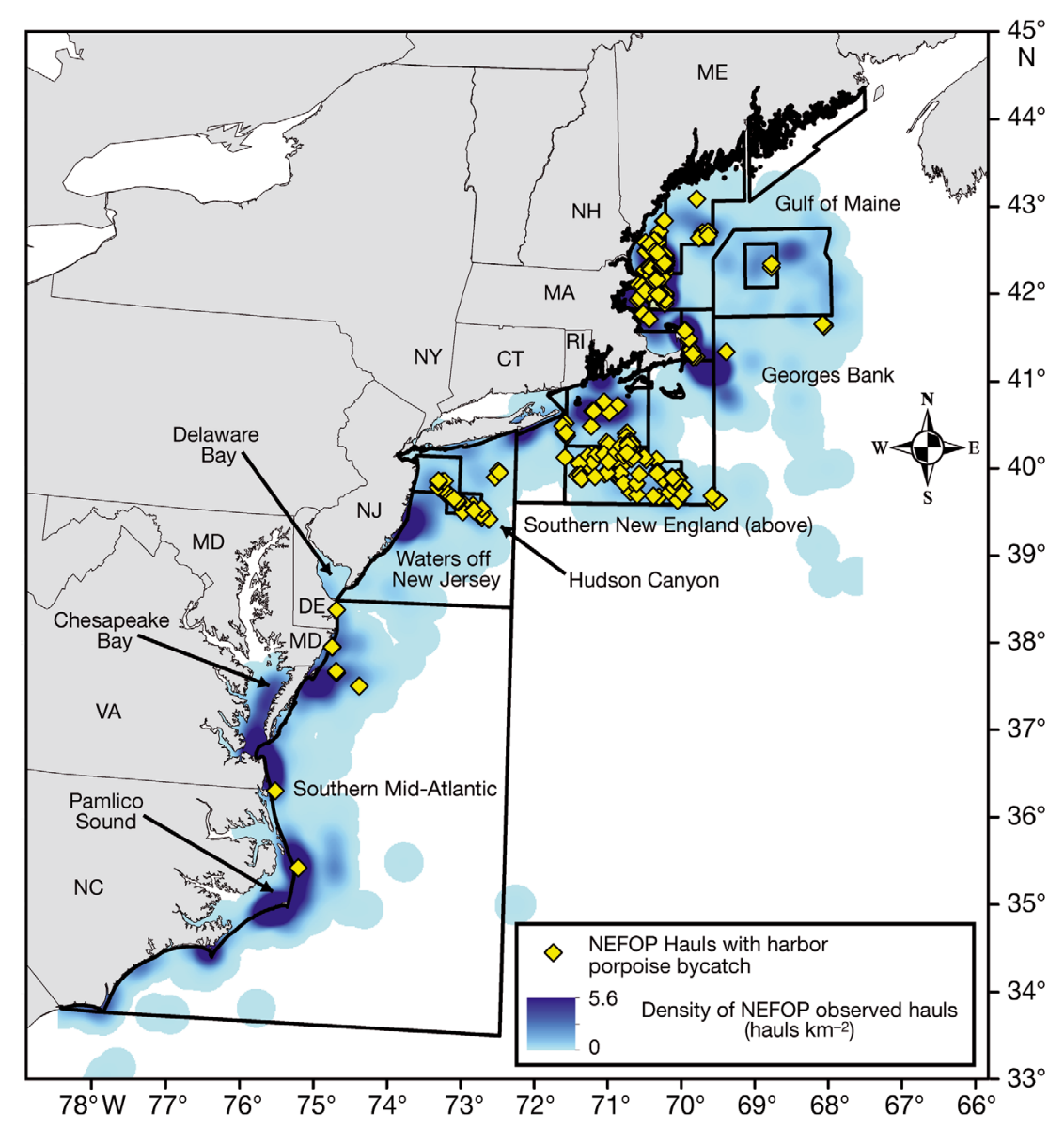

Fig. 4. Location of gillnet hauls observed by the Northeast Fishery Observer Program (NEFOP) and harbor porpoise Phocoena phocoena bycatch, from 1999 through May 2010. Black lines indicate management areas described in Figs. 1, 2, 6 \& 8 
though most string lengths are often half as long or shorter, typically 305 to $457 \mathrm{~m}$ (1000 to $1500 \mathrm{ft}$ ) in length (Orphanides 2011a). However, for some areas and target species, such as fishing for monkfish off New Jersey, the string lengths may be 914 to $1829 \mathrm{~m}$ (3000 to $6000 \mathrm{ft}$ ) in length (Palka et al. 2008). Nets are most frequently anchored to the bottom, though unanchored drift or sink gillnets are also used. Mesh size varies by target species and generally ranges from 6.4 to $30.5 \mathrm{~cm}$ (2.5 to 12 inches) (Waring et al. 2007a); though, the most common mesh sizes are either 10.2 to $15.2 \mathrm{~cm}$ (4 to 6 inches) or 25.4 to $30.5 \mathrm{~cm}$ (10 to 12 inches) (Palka et al. 2008). Mid-Atlantic gillnet fishing is often more targeted on a single species than fishing in New England. This leads to more variability in fishing mesh sizes, soak durations, gear configurations, and general fishing practices in the Mid-Atlantic. Vessels are generally smaller than in New England, and most of the fishing occurs close to shore or inside large bays or sounds such as Delaware Bay, Chesapeake Bay, and Pamlico Sound (Fig. 4). A substantial portion of fishing effort occurs around Hudson Canyon and south along the midshelf. In part because fishing is carried out by smaller boats closer to shore, soak durations are often less than in New England, and it is not uncommon for nets to be set and pulled within the same day. However, some nets, particularly those targeting monkfish, are often left to soak for 4 or more days.

\section{Fisheries management}

Fish catch is managed under the MagnusonStevens Fishery Conservation and Management Act, while marine mammal bycatch is managed by the Marine Mammal Protection Act. These 2 Acts manage their respective marine species with different goals. The Marine Mammal Protection Act aims to keep marine mammal populations at optimum sustainable levels, while the Magnuson-Stevens Act generally aims to keep fish populations only high enough to ensure an optimum yield for fisheries. The MagnusonStevens Act created 8 regional fishery management councils that help to manage regional fisheries by developing FMPs which are evaluated by NMFS, modified if necessary, and then implemented by NMFS.

New England gillnet fishing is managed by a variety of FMPs. The primary FMPs in this region include the Northeast Multispecies FMPs for groundfish and monkfish, although there are also FMPs for skates (Rajidae family) and spiny dogfish. Gillnets, particularly in New England, often catch a variety of species in 1 haul that are managed under different FMPs. Given this mixed catch, there is considerable overlap in the management plans. For example, groundfish FMP regulations often apply to fishing efforts targeting non-groundfish species such as monkfish, dogfish, and skates. Skates are often caught together with monkfish and, with few exceptions, must be landed under a permit for groundfish, monkfish, or scallops (if trawling). Dogfish are targeted with the same mesh size as groundfish and, therefore, generally have to follow the groundfish regulations. Lastly, groundfish permits must often be used to fish for monkfish because of overlapping in regulations.

Over the course of the last decade, the New England groundfish fishery, the dominant fishery in the region, has undergone significant changes. Fisheries managers have worked with the fishing industry to decrease overfishing and the number of overfished species to ensure that the northwestern Atlantic can be sustained as a healthy ecosystem and as a consistently valuable economic resource. The New England gillnet fleet has shrunk over these years; the number of active permit holders in 2009 was about half that of 2002 (Waring et al. 2007b, 2011). However, the fleet has also become more efficient, resulting in fairly stable overall annual metric tons of landings despite the shrinking fleet (Waring et al. 2007b, 2011). Throughout this time period groundfish regulations have changed often. Numerous types of management measures have been put in place, removed, and modified. Some of these measures include special access programs, days at sea restrictions, trip catch limits, and closed areas. The result has been a dynamic suite of regulations combined with seasonal and yearround closures. For additional details on the Northeast Multispecies FMP regulations, see the Northeast Fisheries Management Council website (nefmc.org).

Although many groundfish regulations have changed over the years, several closures have been fairly consistent. Specifically, a series of rolling closures, originally intended to limit the exploitation of Atlantic cod, extending from the shore along eastern Gulf of Maine, open and close in a 'rolling' fashion moving up and down the coast with the seasons and following the annual migration of Atlantic cod. In addition to the rolling closures, a permanent yearround western Gulf of Maine closure has been in place since 1996. Though these closures are primarily for the purpose of protecting cod and other groundfish, it is widely recognized that these areas also serve to greatly limit harbor porpoise bycatch, because harbor porpoise follow a similar annual migration up and down the coast (Murawski et al. 
2005). It was estimated that the western Gulf of Maine closure might reduce annual harbor porpoise bycatch by as much as 585 animals $\mathrm{yr}^{-1}$ (Orphanides \& Palka 2008). The harbor porpoise bycatch reductions provided by these closures were taken into consideration by the HPTRT, though some members were hesitant to rely on them because of the possibility that these closures could be removed or modified based on changes in fish populations but without considering the harbor porpoise bycatch reduction benefits (Mediation Institute 2000b).

Along with the groundfish fishery, the gillnet monkfish fishery is also associated with high harbor porpoise bycatch. Monkfish landings grew considerably in the 1990s. In 1999 monkfish stocks were considered overfished. In response, a monkfish FMP was initiated in November 1999, and the fishery was put into a rebuilding phase. Among the management tools put in place by the FMP were: dividing the fishery into 2 management areas and limiting trips and days at sea. The number of fishing trips was limited in the southern management area (extending from New England and southern Georges Bank, south through the Mid-Atlantic to North Carolina), but the number of trips was not limited in the northern management area (northern Georges Bank and the Gulf of Maine) (Mediation Institute 2000b). The monkfish FMP went through several framework changes over the course of the HPTRP. However, most of these involved changes in the number of allowable days at sea and other limitations, but did not involve large time-area closures (though there was a small closure for spawning habitat). Generally, monkfish stocks were rebuilt over the course of the HPTRP, and, although the population estimates and certainty of these estimates varied over time, monkfish were generally not considered to be overfished after the first few years of the HPTRP (Haring \& Maguire 2008, NEFMC \& MAFMC 2011).

Numerous other gillnet fisheries exist in the MidAtlantic, though from 1999 to 2010 these fisheries did not have a large harbor porpoise bycatch and so will not be discussed in detail here. Some Mid-Atlantic fisheries that did have harbor porpoise bycatch prior to the HPTRP, such as the spiny dogfish and shad fisheries, were largely non-existent shortly after the HPTRP was initiated because of changes in federal and state fisheries regulations unrelated to harbor porpoise management. Since the HPTRP was initiated, the spiny dogfish population was declared successfully rebuilt in 2010, though landings since 2001 were far lower than during the 1990s (Rago \& Sosebee 2010). Management of this fishery is closely tied to groundfish management, since nets set for dogfish often catch the same species assemblage as those set for groundfish. The shad fishery is managed by the Atlantic States Marine Fisheries Commission; however, the shad ocean-intercept fishery is still closed because this species has yet to recover.

\section{Marine mammal monitoring}

The Northeast Fisheries Observer Program puts fisheries observers on a small but representative sample of trips across a number of fisheries. The sample of gillnet trips has been used to estimate bycatch for the entire gillnet fishery and to monitor the effectiveness of the HPTRP. Roughly $4 \%$ of all trips were sampled annually from 1999 to 2010. Mid-Atlantic gillnet coverage was often less than New England coverage, about 2 to $3 \%$ as compared to $5 \%$, respectively. Observers record information on characteristics of the vessel, crew, trip, haul, gear, and catch, including incidental bycatch. Observers also collect data on pinger functionality on a limited sample of trips focusing on marine mammal incidental bycatch. Roughly $45 \%$ of past observed trips have been focused on marine mammal bycatch, though pinger testing did not occur on many of these trips due to difficulties with pinger testers. A more detailed discussion of the development and use of pinger testers is provided in the 'Pinger testing' section of this paper.

\section{HPTRP 1999 to 2010}

\section{Early period, 1999 to 2001}

Harbor porpoise bycatch started dropping in the years prior to the HPTRP due to New England Fishery Management Council actions, many of which were incorporated into the HPTRP (Fig. 3) (Read 2013). In the year prior to the implementation of the HPTRP, the estimated harbor porpoise bycatch was 778 animals, but in the first year of the HPTRP the estimated bycatch dropped by more than half to 323 (Fig. 3). This was the first time that the estimated bycatch was below PBR (747), which was the shortterm goal of the HPTRP. It should be noted, however, that: PBR had increased due to a larger more recent abundance estimate (Waring et al. 2001). It appeared that the mix of closures, pinger requirements, and gear modifications had an immediate impact. In 2000, the estimated bycatch increased to 528, though 
it was still below PBR. Then, in 2001 estimated bycatch decreased to an all-time low of 79 animals. It appeared the harbor porpoise bycatch issue had been solved, though this success was short-lived.

Possible reasons for the low bycatch during this period were high compliance to the HPTRP, the implementation of several fishery management plans, and natural inter-annual variability of environmental factors. When the HPTRP was implemented in 1999, mechanisms were put in place to encourage compliance. As part of the HPTRP, fishermen were required to attend a pinger training program if they wanted to fish in areas where pingers were required. Also, NMFS conducted outreach and education when the HPTRP was implemented. In addition, some incidental outreach had already occurred as a result of fishermen working towards a way to reduce bycatch prior to the HPTRP implementation (Read 2013).

Despite the decrease in bycatch during the first years of the HPTRP, members of the Gulf of Maine HPTRT remained concerned about compliance with the HPTRP in New England. During the first few years of the HPTRP, compliance was not immediately estimated. It was not until 2007 that analyses revealed that compliance with closures was poor in the Mid-Atlantic but good in New England, and in most times and areas where pingers were required, between 50 and $80 \%$ of the observed hauls had at least $90 \%$ of the required number of pingers on their nets (Palka et al. 2008, Orphanides 2011b). This is particularly important because in areas where pingers were required, gillnet strings with fewer pingers than required were found to have bycatch rates 2 to 3 times higher than those with the full complement of pingers (Palka et al. 2008). In areas where pingers were mandated, fishermen were required to have 1 pinger between each net, and 1 on each end of the string of gillnets. Comparison of compliance percentages across the HPTRP time period is complicated by the fact that a $90 \%$ cutoff was used to determine compliance with pinger regulations from 1999 to the spring of 2008. This allowed for situations where a pinger may have fallen off the net during fishing. In contrast, a $100 \%$ pinger use cutoff was used when determining compliance thereafter. Despite these differences, the general trends remain comparable even though compliance with pinger regulations for the early and middle part of the HPTRP may be slightly overestimated.

New fishery management plans also appear to have assisted in the reduction of harbor porpoise bycatch by reducing fishing effort in key fisheries. In 1999 and 2000, new FMPs were instituted for the monkfish, spiny dogfish, and American shad fisheries, all of which were significant contributors to harbor porpoise bycatch in the Mid-Atlantic. The 1999 monkfish FMP allowed a very limited number of trips in the southern management area (Haring \& Maguire 2008). In 2000, the spiny dogfish FMP sharply limited landings in federal waters and the Atlantic States Marine Fisheries Commission took emergency action to close spiny dogfish harvest in state waters. Also, in 2000, the Commission began a 5 -yr phase-out plan for the ocean intercept American shad fishery. Perhaps as an effect of both the FMPs and HPTRP, during the 1999 to 2001 time period, there was no observed bycatch in the Waters off New Jersey and few observed bycatch events in the Southern Mid-Atlantic and Southern New England regions (Table 3, Fig. 5).

Another factor that could have influenced the low bycatch in this time period is the natural inter-annual variability of environmental factors that affect the distribution and abundance of harbor porpoises and targeted fish species. Palka et al. (2009) found that in the New Jersey area and in the Gulf of Maine, the bycatch rate of harbor porpoises during this period was statistically related to sea-surface temperature (SST) and to the winter North Atlantic Oscillation (NAO) index value. The chance of bycatch increased with decreasing water temperatures in both regions (a higher than average bycatch in waters $<7^{\circ} \mathrm{C}$ off New Jersey and $<12.5^{\circ} \mathrm{C}$ in the Gulf of Maine) and increased with lower NAO values $(<0.25$ off New Jersey and $<0.15$ in the Gulf of Maine).

Table 3. Phocoena phocoena. Observed number of harbor porpoises bycaught from 1999 through May of 2010, by year and region, using data collected by the Northeast Fisheries Observer Program. GOM: Gulf of Maine; SNE: Southern New England; WNJ: Waters off New Jersey; SMA: Southern Mid-Atlantic

\begin{tabular}{|cccccc|}
\hline Year & GOM & SNE & WNJ & SMA & Total \\
\hline 1999 & 13 & 1 & 0 & 3 & 17 \\
2000 & 10 & 5 & 0 & 1 & 16 \\
2001 & 2 & 0 & 0 & 1 & 3 \\
2002 & 8 & 3 & 0 & 0 & 11 \\
2003 & 9 & 3 & 1 & 0 & 13 \\
2004 & 14 & 13 & 0 & 2 & 29 \\
2005 & 37 & 14 & 15 & 0 & 66 \\
2006 & 8 & 18 & 27 & 0 & 53 \\
2007 & 3 & 32 & 0 & 1 & 36 \\
2008 & 18 & 12 & 9 & 0 & 39 \\
2009 & 24 & 9 & 6 & 1 & 40 \\
2010 & 5 & 8 & 8 & 0 & 21 \\
Total & 151 & 118 & 66 & 9 & 344 \\
\hline
\end{tabular}


$\diamond$ NEFOP Observed Harbor Porpoise Bycatch Density of NEFOP Observed Hauls (hauls $\mathrm{km}^{-2}$ )
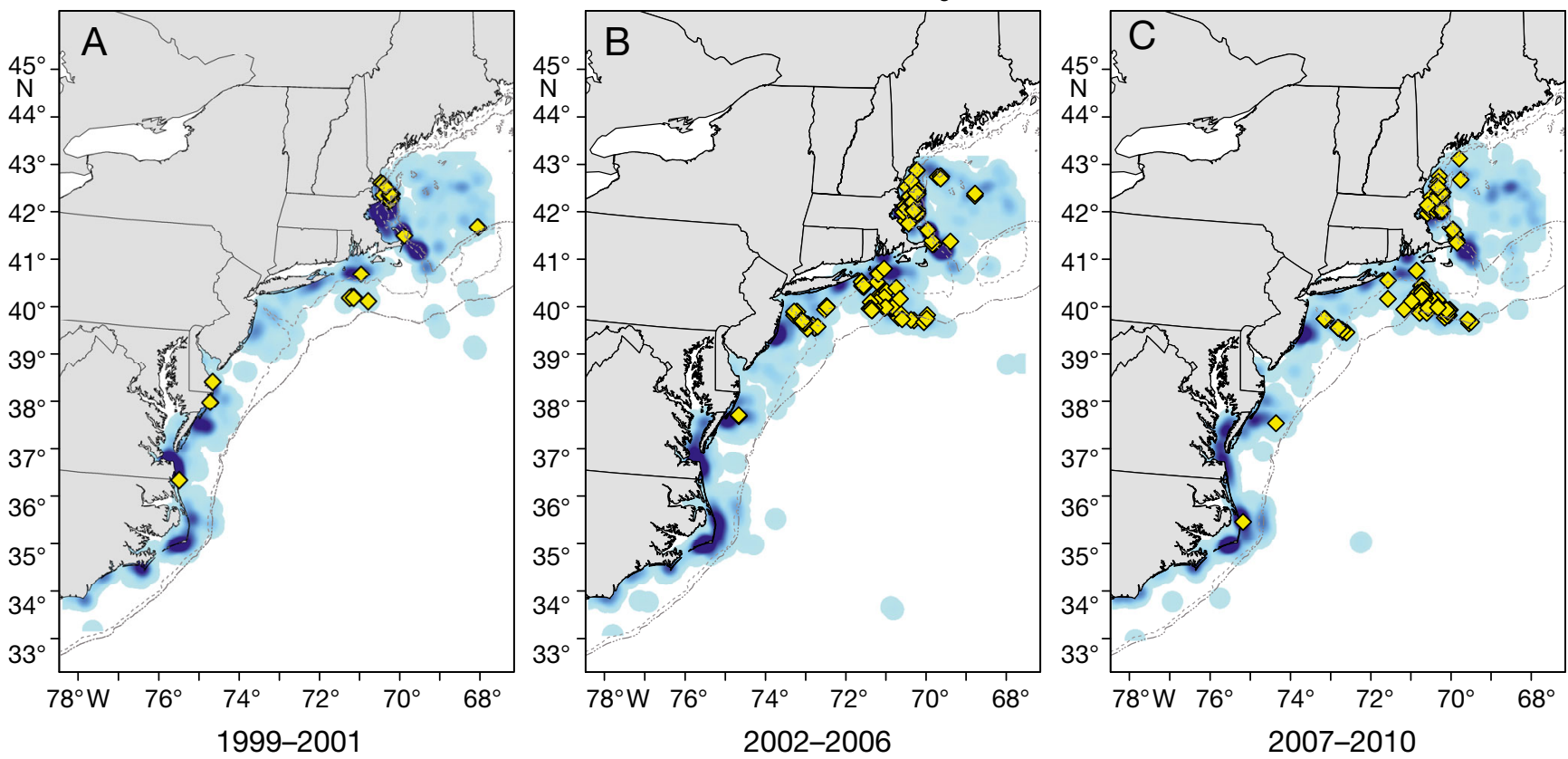

Fig. 5. Location of gillnet hauls observed by the Northeast Fishery Observer Program (NEFOP) and harbor porpoise Phocoena phocoena bycatch, from 1999 through May of 2010, divided into the time periods (A) 1999 to 2001, (B) 2002 to 2006, and (C) 2007 to 2010. The 50 and $100 \mathrm{~m}$ depth contours are also shown

Middle period, 2002 to 2006

From 2002 to 2005 the total estimated US harbor porpoise bycatch for all gillnets increased steadily from its all-time low of 79 in 2001 to 1100 in 2005, and then remained high at 1025 in 2006 (Fig. 3) (Waring et al. 2009). Bycatch in Canadian waters was unknown after 2002 because monitoring in the harbor porpoise stock's range ended. During this period, the total annual estimated bycatch in New England did not change greatly (low of 444 and high of 654) and actually decreased in 2005 and 2006. However, the annual bycatch estimate for the Mid-Atlantic increased each year from 76 in 2003 to 511 in 2006 (no estimate was produced in 2002 for this area because of unrepresentative sampling) (Waring et al. 2009). The harbor porpoise abundance estimate from 2002 to 2004 was 89700 animals, which resulted in a PBR of 747 (Waring et al. 2007a). Though bycatch was steadily increasing, by 2004, the 5-yr mean annual mortality (used as a benchmark by the NMFS to trigger a TRT) had not yet surpassed PBR, though individual years did. By 2005 the abundance estimate changed slightly to 89054 , but the statistical confidence in this estimate decreased due to the use of a different data collection platform (the coefficient of variation, $\mathrm{CV}$, increased from 0.22 to 0.47 ). The lower statistical confidence resulted in a lower PBR of 610 . At the same time, the 2005 annual bycatch estimate increased to 1100 , pushing the 5 -yr mean annual mortality to 652, just slightly above PBR (Waring et al. 2007b). By the time the 2006 bycatch estimate was available, it became clear that the harbor porpoise bycatch problem was far from solved, and in fact appeared to be getting worse. Consequentially, a HPTRT meeting was scheduled in 2007 to address this increase in bycatch.

The increased bycatch during this period appears to have been driven by several factors, including a fishing effort shift into areas not managed under the HPTRP, increased effort targeting monkfish, inter-annual variability in environmental factors, and poor compliance with regulatory mandates. During this period new bycatch patterns emerged. In the Gulf of Maine, fishing effort, and thus harbor porpoise bycatch, increased in the Stellwagen Bank area (Fig. 6), just east of the Massachusetts Bay management area (Fig. 1). Stellwagen Bank was known to have bycatch rates similar to the adjacent Massachusetts Bay management area, but fishing effort there had been low prior to the implementation of the HPTRP. The increased effort in this region could be due to changes in target species distribution, or perhaps to HPTRP seasonal closures 
or pinger requirements in the neighboring Massachusetts Bay management area.

Bycatch also increased in southern New England south of the Cape Cod South management area (Fig. 1) along the outer shelf as gillnet fishing effort that targeted monkfish expanded into this area (Figs. 5 \& 7, Table 3). Directed monkfish fishing effort increased through the 1990s, and much of that fishing effort switched from using trawls to gillnets. The percent of monkfish landed with gillnets (as compared to other gear types) in this region grew from $<1 \%$ in the 1990 s to $50 \%$ by the end of the decade and roughly $65 \%$ by 2006 (Haring \& Maguire 2008). Monkfish landings also increased in the Gulf of Maine, though not to the extent as in the south of the Cape Cod area (Haring \& Maguire 2008). Expansion of the monkfish fishery had a disproportionate impact on harbor porpoise bycatch (Fig. 7) because fishing characteristics associated with monkfish gillnetting are associated with high bycatch rates. That is, gillnetting for monkfish typically involves large mesh (30.5 cm [12 inches], stretched mesh), long gear

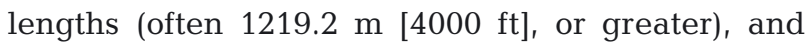
long soak durations (often 4 or more days), all of which have been associated with high bycatch rates (Orphanides 2009, Palka et al. 2009).

In the Mid-Atlantic, particularly in the Hudson Canyon area off New Jersey, observed monkfish effort increased, leading to large increases in the observed takes and annual harbor porpoise bycatch estimates (Table 3, Fig. 7). Observed gillnet fishing effort in this region had disappeared immediately after the HPTRP with the advent of the monkfish and spiny dogfish FMPs, only to rebound after 2002 with corresponding increases in harbor porpoise bycatch, especially in 2005 and 2006 (Table 3). However, estimating bycatch for the Mid-Atlantic is challenging because it is on the southern end of the harbor porpoise range, and, thus, bycatch can vary substantially between seasons and years, depending on the extent to which harbor porpoise occupy the area. In addition, bycatch estimates for the Mid-Atlantic are more

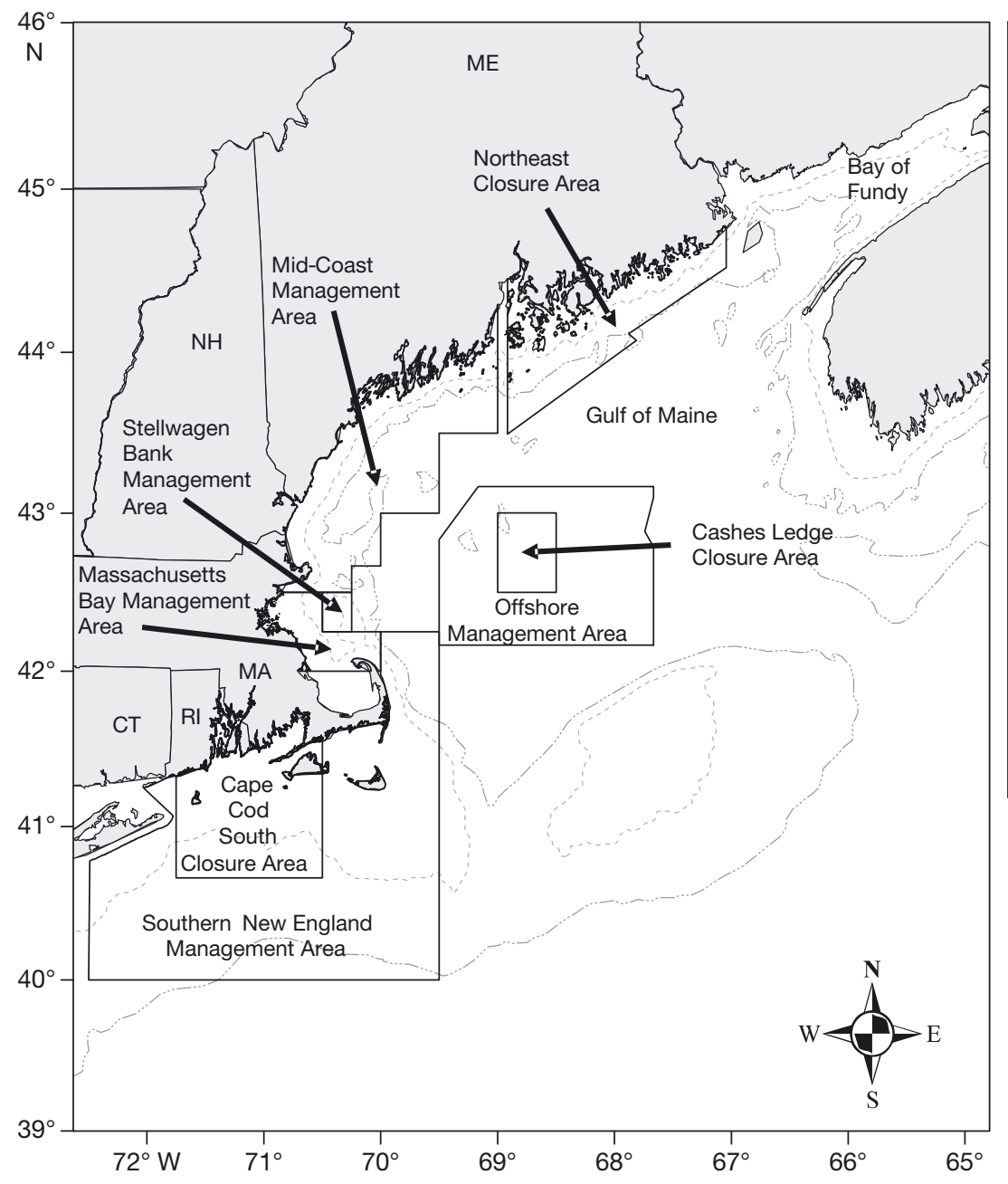

\begin{tabular}{|c|}
$\begin{array}{c}2010 \text { HPTRP Management } \\
\text { and Closure Areas }\end{array}$ \\
\hline Northeast Closure Area \\
NO GILLNETS: Aug 15 - Sep 13 \\
Mid-Coast Management Area \\
PINGERS ONLY: Sep 15 - May 31 \\
Massachusetts Bay Management Area \\
PINGERS ONLY: Nov 1 - Feb $28 / 29$ \\
NO GILLNETS: Mar 1 - Mar 31 \\
PINGERS ONLY: Apr 1 - May 31 \\
Stellwagen Bank Management Area \\
PINGERS ONLY: Nov 1 - May 31 \\
Offshore Management Area \\
PINGERS ONLY: Nov 1 - May 31 \\
Cashes Ledge Closure Area \\
NO GILLNETS: Feb 1 - Feb $28 / 29$ \\
Cape Cod South Closure Area \\
NO GILLNETS: Mar 1 - Mar 31 \\
Southern New England Management Area \\
PINGERS ONLY: Dec 1 - May 31 \\
\hline
\end{tabular}

Fig. 6. Modifications to the Harbor Porpoise Take Reduction Plan (HPTRP) for New England gillnet management and closure areas agreed upon in 2008 and implemented in 2010. The 50 and $100 \mathrm{~m}$ depth contours are shown 


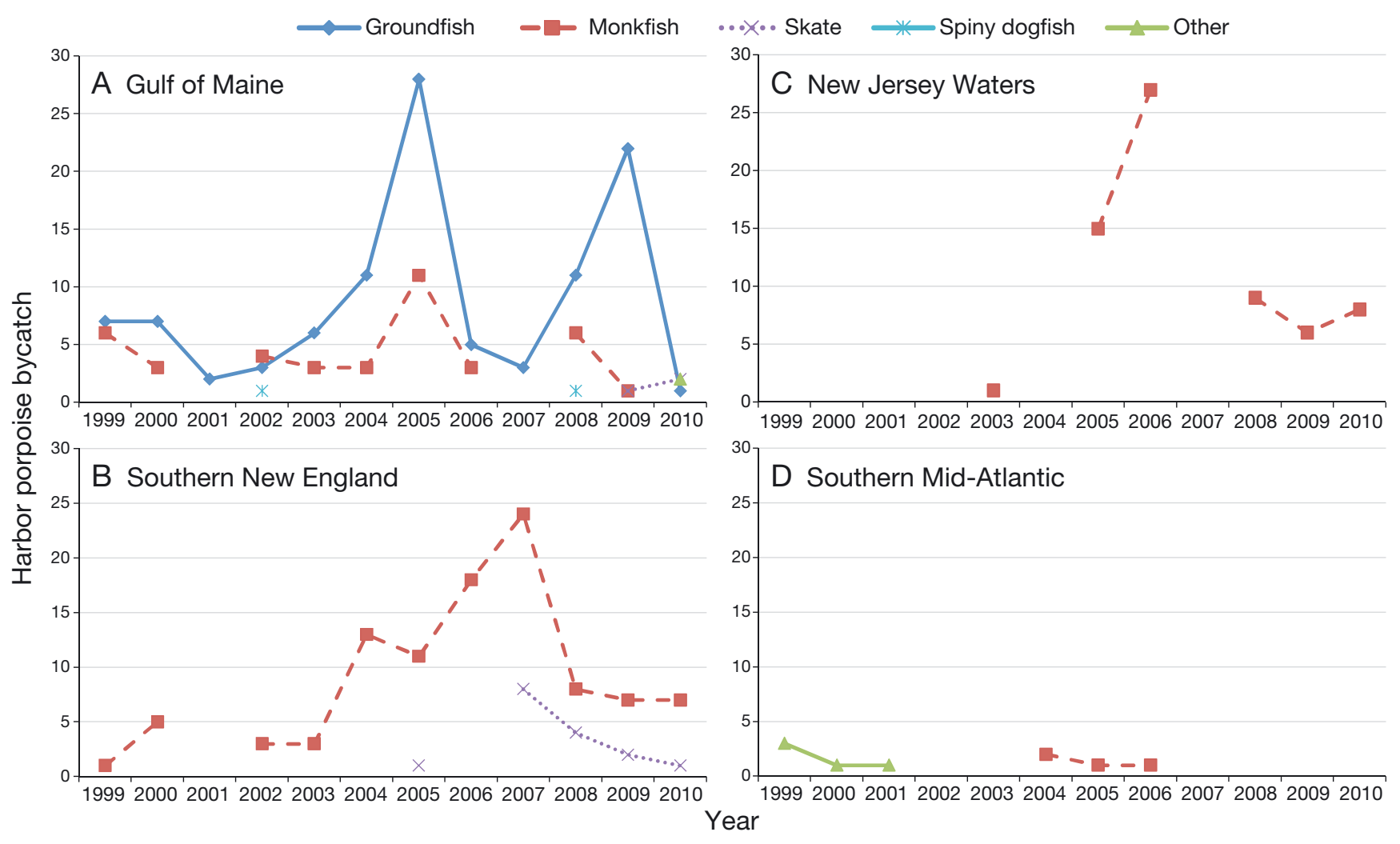

Fig. 7. Observed harbor porpoise Phocoena phocoena bycatch ( $\mathrm{n}=$ number of harbour porpoises) by target species, year, and region: (A) Gulf of Maine, (B) Southern New England, (C) Waters off New Jersey, and (D) Southern Mid-Atlantic. Gaps in data indicate no harbor porpoise observed caught for that target species in that year

variable due to the low observer coverage in this area (typically 2 to $3 \%$ ), making it difficult to document a relatively rare event (harbor porpoise bycatch).

Some of this inter-annual variability, both in the Mid-Atlantic and in New England, may have been related to natural variability of environmental factors associated with harbor porpoise distribution. The same environmental factors which may have reduced harbor porpoise bycatch from 1999 to 2001 (i.e. SST and NAO) could have made for conditions that increased the likelihood of bycatch events during the period from 2002 to 2006.

Another possible contributing factor to high bycatch during this period was decreased compliance. In the Mid-Atlantic, compliance with closed areas was poor (Orphanides 2011b). In New England, Palka et al. (2008) showed a general decline in pinger use since the inception of the HPTRP, which bottomed out in 2003, 2004, and 2005, depending on the region examined. At some point during this $3 \mathrm{yr}$ period, use of the required number of pingers for each management area dropped to $<25 \%$, i.e. $75 \%$ or more hauls in HPTRP management areas did not have the proper number of pingers on the nets.
To increase compliance, NMFS initiated an outreach and enforcement program. In 2004, because of observed fishing in closed areas, NMFS mailed a permit holder letter to the gillnet industry reminding them of the March closure in the Massachusetts Bay management area. In 2005, NMFS mailed another permit holder letter that provided an information sheet summarizing the HPTRP regulations and depicting the management areas on nautical charts. In late 2006 through early 2007, enforcement patrols were conducted by the Coast Guard and separately by states coordinating with NMFS, and 9 voluntary industry outreach meetings were held from Maine through Virginia where industry members were provided with the latest information on harbor porpoise abundance and bycatch, a review of the HPTRP requirements, and pinger training where needed. NMFS also created new laminated outreach placards in October 2006 detailing the HPTRP areas and requirements, and mailed those to all gillnet fishermen who had previously received pinger training. This mailing included a laminated copy of their pinger training authorization to ensure these were kept on board the vessels when fishing inside pinger 
management areas. Finally, NMFS published information in trade publications in an effort to update fishermen on the status of the harbor porpoise stock and to remind them of the HPTRP requirements (NOAA Fisheries 2010).

In summary, a number of factors converged during this time period, resulting in increasing harbor porpoise bycatch. Fishing effort expanded into areas unregulated by the HPTRP; much of this was monkfish fishing effort, which has fishing characteristics associated with high levels of bycatch. Furthermore, compliance with regulatory mandates dropped to the lowest level seen during the HPTRP. Lastly, environmental factors may also have favored an increase in the overlap between fisheries and harbor porpoise occurrence.

\section{7 and 2008 HPTRT meetings}

In December 2007, NMFS reconvened the HPTRT to address the recent increases in bycatch in the entire region from the Mid-Atlantic through the Gulf of Maine. This was then followed by an HPTRT conference call in January 2008 (CONCUR 2008a,b). The HPTRT focused on ways to address the main causes of increased bycatch, which were thought to be non-compliance with the current HPTRP requirements and an increase in bycatch occurring outside of the current HPTRP management areas. As had happened at past HPTRT meetings, TRT members stressed that proposed management actions should be readily enforceable, and that enforcement needs to occur in an effective and consistent manner. Discussions centered on possible solutions for the Gulf of Maine and Southern New England bycatch, which included expanded pinger regulations and additional closures. Eventually, the HPTRT crafted a consensus plan for New England that included expanded pinger zones and closures that would be enacted only if target bycatch rates were not met.

The final plan involved creating a new closure in the Mid-Atlantic adjacent to the existing Mudhole closure called the Mudhole South closure, creating a Southern New England management area that expanded pinger use requirements in the area south of New England and east of Cape Cod, expanding the duration of the Massachusetts Bay management area regulations to include November, and creating the Stellwagen Bank management area adjacent to the Massachusetts Bay management area (Fig. 6). The addition of these new management areas was intended to address the increased bycatch in the
Waters off New Jersey management area, south of the Cape Cod South management area, and east of the Massachusetts Bay management area. Also included were plans for aggressive outreach and enhanced enforcement by cooperating states, in part by attempting to incorporate the HPTRP gear modifications into state regulations, allowing the states to more easily enforce the HPTRP regulations. The modifications to the HPTRP also called for close coordination between states and federal agencies and for alignment of various boundaries to eliminate gaps and inconsistencies.

In addition, to provide an incentive for increased pinger compliance in areas with historically high harbor porpoise bycatch levels, the possibility of further seasonal closures was enacted in what was termed the consequence closure area (CCA) strategy (Fig. 8). Under this strategy, if the average bycatch rate within 2 consecutive management seasons in certain areas exceeds a specified target bycatch rate, then a seasonal closure is triggered. These target bycatch rates would result in bycatch below PBR and were set to match the bycatch rates of observed hauls in those areas that were known to have the correct number of

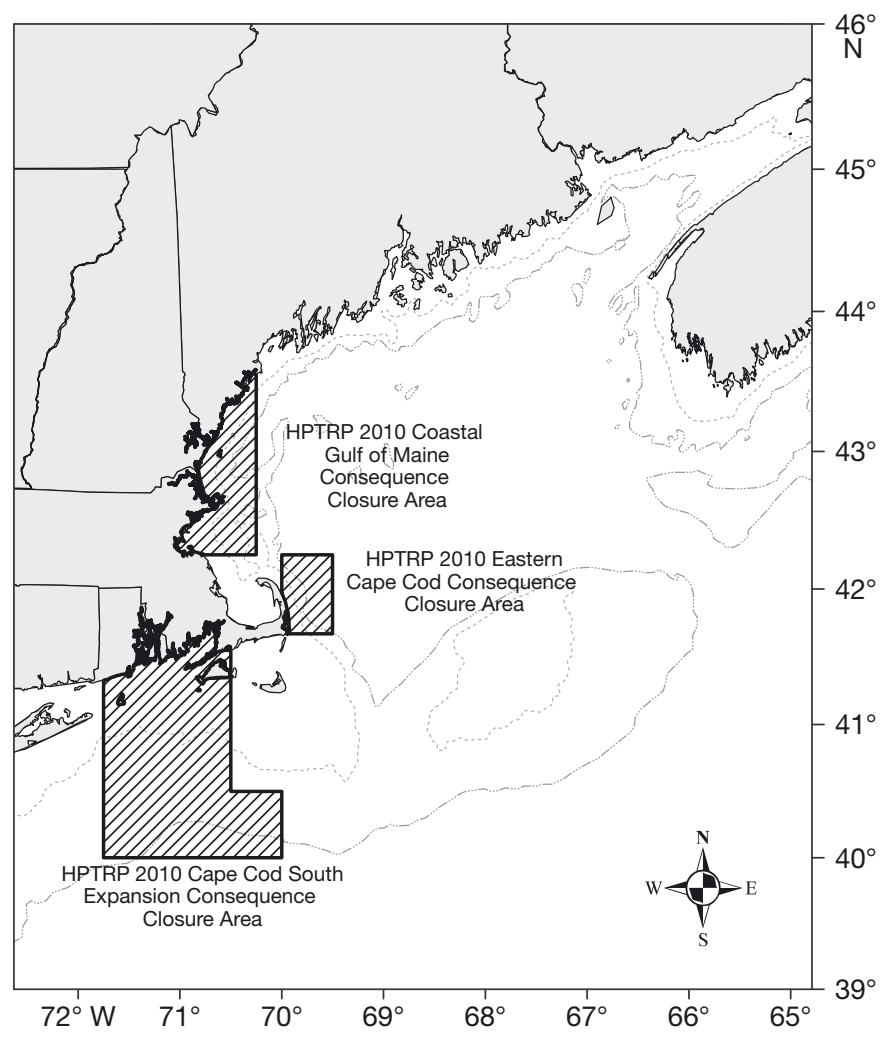

Fig. 8. New England gillnet Consequence Closure Areas (CCAs; hatched boxes) incorporated into the Harbor Porpoise Take Reduction Plan (HPTRP) in 2010 and agreed upon in 2008 
pingers deployed between 1 January 1999 and 31 May 2007 (Palka et al. 2008). Thus, the target bycatch rates were set to match rates that were achieved by observed hauls that had the correct number of pingers. Since it was known that some unknown percentage of the pingers on the nets was not working, the target bycatch rate included hauls with some non-functional pingers, and so the resulting target bycatch rates were higher than the rate expected from hauls with all of the pingers working and present.

Late period, 2007 to 2010

Most of the HPTRP modifications were agreed upon by the spring of 2008, and a proposed rule was published in July of 2009. Regulations were enacted in the winter of 2010, with most of the regulations coming into effect in the fall of 2010. For this late time period, 2007 to 2010, the observer data were used to examine whether the HPTRT effort in late 2007 and the preceding outreach in 2006 made a difference in the bycatch during 2007 through the spring of 2010. Granted, this was before the new regulations went into effect, but it is possible that outreach and HPTRT meetings could have promoted an increased awareness, resulting in improved compliance with existing HPTRP regulations and less bycatch.

At first glance it appears that the 2006 outreach effort, combined with knowledge of the upcoming HPTRT meeting, may have reduced bycatch. In 2007 , bycatch in both New England and the Mid-Atlantic dropped to levels not seen since 2001 (395 and 58, respectively, 453 total). Bycatch in the Waters off New Jersey region dropped from the levels seen in 2005 to 2006, though bycatch south of New England was still very high both inside and outside of HPTRP management areas. Nevertheless, the 2007 annual bycatch estimate (453) was below PBR (703), though the 5 yr mean mortality (807) was still above PBR. The annual abundance estimate stayed at 89054 , though PBR increased from 610 to 703 because of research that provided new estimates of maximum net productivity for the species. There was also a large improvement in pinger use, when between 50 and $80 \%$ of gillnet hauls used the required number of pingers. The Mid-Coast management area had a low of $50 \%$ and the Offshore management area had a high of $80 \%$ (Palka et al. 2008). Although this was an improvement over compliance during the period from 2002 to 2006, compliance was still far from $100 \%$. However, the drop in bycatch proved short- lived. In 2008 the annual bycatch estimate (1016) returned to the higher levels of 2005 and 2006, followed by a more moderate level in 2009 (792), though bycatch levels remained above PBR (703).

As part of the monitoring plan for the HPTRP, NMFS prepared reports summarizing harbor porpoise bycatch rates, HPTRP compliance, and pinger use rates. These reports documented that compliance with the HPTRP was generally poor in the years after the 2007 HPTRT meeting (Orphanides et al. 2009, Orphanides 2010, 2012). Non-compliance was similarly poor in both New England and the MidAtlantic, with compliance estimates by region ranging from 42 to $66 \%$. Non-compliance in the Mid-Atlantic included violations of both closed area restrictions and required gear modifications. In contrast, New England observed effort was always in compliance with closed areas, though non-compliance with pinger requirements was high.

\section{ENFORCEMENT}

From the start of the HPTRP, enforcement was seen as critically important to its success (Mediation Institute 2000b). It was assumed that increased enforcement would lead to better compliance, and that better compliance with the HPTRP regulations would then lead to decreased harbor porpoise bycatch.

The Coast Guard is the primary at-sea enforcer of HPTRP regulations. NMFS conducted additional atsea patrols with state law enforcement through Joint Enforcement Agreements (JEAs). The US Coast Guard has described monitoring the HPTRP as a routine component of their activities and those of several state enforcement partners. As of 2007, the Coast Guard had goals of 20 aircraft and/or cutter (vessel) hours per week devoted to HPTRP closures and pinger enforcement across Coast Guard District 1 (New York through Maine), in addition to operations with NMFS and state law enforcement partners. In addition, the Coast Guard has occasionally done targeted pulse operations, sometimes jointly with state agencies, where a specific time and area is targeted for compliance with HPTRP and Large Whale Take Reduction Plan regulations (NMFS 2007).

NMFS provided state enforcement partners in Maine, Massachusetts, and Rhode Island with inwater pinger detectors in 2008 that could be placed in the water above a net to determine if at least 1 pinger was working. However, these detectors could aid in enforcement only when no pingers were being used because the detectors could not indicate if the 
proper number of pingers were on a net or if all of the pingers present were working. Data provided by these detectors has been limited, and it is unclear how they have been used, and if they were effective.

Throughout the HPTRP, HPTRT members raised concerns over the perceived low level of enforcement and the lack of compliance with HPTRP regulations (Mediation Institute 2000b, CONCUR 2008a). In general, published HPTRP enforcement data were difficult to obtain and not well documented. Most of the limited enforcement data found were from New England, with mention of 1 targeted operation in the Mid-Atlantic. The data that were available were often incomplete; for example, violations may have been noted, but the outcome of the case was not reported.

Data provided by the Coast Guard at HPTRT meetings included a total of 5 pinger violation cases in 1999, 2000, 2006, and 2007 (Mediation Institute 2000b, NMFS 2007), though it was not clear how many vessels each year were boarded or checked for violations. Details were provided on the number of boardings for targeted pulse operations, but not for routine monitoring. The HPTRT was told that targeted patrols of the Massachusetts Bay and Northeast management areas in 2005 saw no gillnet vessels, and, in 2006, 7 vessels were boarded during targeted patrols of Massachusetts Bay, but no HPTRP violations were found. In targeted patrols during 2007, 16 gillnet vessels were boarded in the Cape Cod South management area, and 3 in the Mudhole management area, but no violations were found (NMFS 2007).

There are not enough available quantitative enforcement data to characterize HPTRP enforcement or to evaluate the influence of enforcement on compliance, except to say that observed compliance with the HPTRP varied over time but was generally low. Thus, assuming increased enforcement would result in increased compliance, whatever the level of enforcement, it was not sufficient to promote sustained compliance. One possible reason for low levels of enforcement is that the HPTRP regulations were perceived as challenging to enforce. The HPTRP regulations varied by time and area and differed from other TRT regulations. Also, evidence of non-compliance with gear restrictions was difficult to collect at sea because Coast Guard policy did not allow them to haul up nets to check the gear characteristics (Mediation Institute 2000b). To check pinger or gear modification requirements the Coast Guard would have to ask fishermen to pull up their nets or be present when the nets were being hauled, and in-water pinger testing equipment had limited effectiveness since the number of pingers on a net could not be detected. Lastly, an additional complication in penalizing violators of the HPTRP was that there was no penalty schedule specific to the HPTRP when it began. A penalty schedule was eventually developed for TRTs in general, but nothing specific was developed for the HPTRP and its pinger requirements.

\section{PINGER TESTING}

Testing the functionality of pingers is important because the effectiveness of part of the HPTRP depends on pingers to reduce bycatch. Fisherman reported that some early pinger models had a high failure rate. However, when the HPTRP started, observers only recorded the number of pingers on a string but did not have a reliable way to test whether they were working. To address this problem, NMFS set out to develop a pinger tester for use by observers. The aim was to help assess the true level of compliance with pinger regulations and assess the effectiveness of pingers at reducing bycatch.

To obtain this information, the observer program developed data collection protocols. Pinger information was collected only on trips focused on observing marine mammal incidental bycatch, as compared to those trips focused on fish catch. These marine mammal trips accounted for about $45 \%$ of all observed hauls in New England from 1999 to 2010, though this percentage varied by year and generally decreased after 2003. However, not all marine mammal-focused trips were equipped with pinger detectors. On marine mammal-focused trips that did have pinger testers, the observer was directed to test the functionality of each pinger as the net was hauled on board. On trips focusing on fish sampling, if a marine mammal incidental take occurred, the observer was instructed to test the pinger located before the incidental take and to test the remaining pingers on that string as they were hauled on board (Palka et al. 2008). If a marine mammal incidental take occurred and the observer did not have a pinger tester, the observer was still required to document whether the remaining pingers were working by listening to the pingers as they were hauled back (Northeast Fisheries Observer Program 2013); in practice, however, this was not always done.

NMFS started developing a pinger tester for use by observers in the late 1990s. At the December 2000 HPTRT meetings, NMFS stated that progress developing a pinger tester had been slow, but that a proto- 
type appeared ready to be produced for agency use (Mediation Institute 2000b). Despite the optimistic prediction at this meeting, pinger tester development continued to be slow and was plagued by technical problems. In fact, pinger testers would not be ready for use until late in 2003 when use of pinger testers became a regular component of the observer program (Palka et al. 2008).

In 2003, 12 pinger testers were distributed to observers in times and areas where pingers were required; however, there were too few testers to equip all observers. Unfortunately, the pinger testers were not robust, so over the next few years the pinger tester was removed from the field and redesigned for improved durability and reliability. Four of the redesigned testers were put back into the field and collected data during 2006 and 2007. From 1999 through the spring of 2007, 69 gillnet strings were checked with pinger testers, totaling 813 pingers. Over these years, $80 \%$ of pingers tested were working, though in a year with low pinger usage (2003), only $36 \%$ were recorded working (Palka et al. 2008).

From the fall of 2007 through the spring of 2010 few pinger testers were used on observed trips as NMFS worked towards a new pinger tester design while also reconfiguring and repairing existing pinger detectors (Orphanides et al. 2009). The limited pinger tester data that was available from 2007 to 2010 suggest that roughly $80 \%$ of the pingers tested were functional - the same as from 1999 to 2007 (Palka et al. 2008, Orphanides et al. 2009, Orphanides 2012). During the 2009 to 2010 HPTRP season, observers with pinger testers were on 7 trips with 22 hauls. Of these, only 6 hauls had the proper number of pingers on their nets, and only 1 of these 6 hauls had all pingers functional. While this is informative, the small sample from 2009 to 2010 was not sufficient for statistically meaningful analysis of broad trends.

Even though the pinger functionality sample size from 1999 to 2010 is relatively small, the data suggest that even when the proper number of pingers was used, they may not have all been functional. This makes estimating true compliance (when all pingers were functional and also present in the required numbers) challenging. It also makes it difficult to quantify the effectiveness of pingers in reducing bycatch. Lastly, using roughly $20 \%$ non-functioning pingers is troubling because Palka et al. (2008) showed that, if fewer pingers were used than required, the bycatch rate was 2 to 3 times higher than if the correct number of pingers were used.

\section{SUMMARY AND DISCUSSION}

Over the course of the HPTRP, harbor porpoise bycatch was reduced during the early years, rose during the intermediate years, and then became moderate in the later years. Though bycatch fluctuated, it was not reduced sufficiently to maintain the mean annual mortality below PBR in the later years. The major reasons for the fluctuations appear to be changes in the fisheries and poor compliance with HPTRP management measures.

For example, the decline of key fisheries played a large role in reducing bycatch in the Mid-Atlantic, especially during the early years of the HPTRP. However, these bycatch reductions did not persist when observed monkfish effort off New Jersey rebounded and there was poor compliance with both the required gear modifications and seasonally closed areas. Similarly, bycatch in Southern New England increased significantly starting in 2004, apparently associated with the expansion of the monkfish fishery to new areas that were not managed under the HPTRP and with gillnet fishing effort increasing because fishermen switched from using trawls to using gillnets to target monkfish (Haring \& Maguire 2008).

Bycatch in the Gulf of Maine fluctuated throughout the HPTRP and appears to have been linked to compliance with HPTRP management measures. Compliance with pinger regulations has proved challenging. Non-compliance was defined as missing 1 or more pingers and/or using non-functioning pingers. Though this appears to be a strict definition, missing just a few pingers results in higher bycatch rates (Palka et al. 2008). Bycatch generally had an inverse relationship with compliance, where years with poor compliance with pinger regulations often resulted in higher annual bycatch estimates. For example, compliance was particularly low from 2003 to 2005, dropping to $<25 \%$, and annual bycatch estimates increased to their highest levels during these same years (Palka et al. 2008). Yet, even when compliance with pinger regulations improved, it still never approached anything close to $100 \%$ compliance, and bycatch was not maintained below PBR (Palka et al. 2008, 2009, Orphanides 2009, 2010, 2012).

Even when the correct numbers of pingers were on the strings, pingers appear to have not been as effective in reducing bycatch in the operational fisheries as they had been during the original scientific experiment, enabling reductions of 50 to $80 \%$ in the operational fishery as compared to $92 \%$ in the original scientific experiment (Allen et al. 1999, Rossman 2000, Palka et al. 2008, Orphanides 2009, 2010, 
2012). The range in observed bycatch reduction (50 to $80 \%$ ) appears to be influenced by environmental and fishery inter-annual variability combined with variability associated with observing a rare event (harbor porpoise bycatch). It is also likely that at least some of the reduced effectiveness of pingers in the operational fishery is associated with the deployment of non-functional pingers, which did not occur in the original scientific experiment. Unfortunately, assessing the effectiveness of pinger use has been hampered by being unable to reliably know whether most pingers are functioning. NMFS has made efforts to better assess pinger functionality, although this proved more difficult than originally anticipated.

Throughout the HPTRP, the degree of enforcement was difficult to quantify, but there are indications that enforcement effort was insufficient to encourage compliance. Low levels of enforcement were probably due to a number of factors, one of which is that gear modifications and pinger use requirements are difficult to observe and thus enforce. To observe noncompliance with pinger and gear modification requirements the Coast Guard must be present when nets are hauled in by fishermen. In-water pinger detectors could help enforcement agents determine whether pingers are being used on a string of nets, but the detectors will not help assess whether the correct numbers of pingers are present and functional.

This review suggests that, for management actions to be effective, steps must be taken to ensure compliance with the management actions. Regulatory measures should also be broad enough and flexible enough to allow for changes in the relevant fisheries and the effects of variability in the environment. This review also suggests that pingers are still an effective way to deter harbor porpoise bycatch, though they will have a reduced effect if they are not all working and are not present in the required numbers. Seasonal closures can reduce bycatch if properly placed in space and time. However, closures also require compliance to be effective. Lastly, changes in fisheries management plans, target fish stocks, and fishing behaviors should be monitored, as these changes can have a substantial impact on marine mammal bycatch, particularly if bycatch reduction management plans are not flexible enough to adjust accordingly.

Acknowledgements. We thank Kathryn Bisack for helpful discussions on HPTRT enforcement and compliance, Melissa Vasquez for assistance summarizing the major fisheries management changes over $12 \mathrm{yr}$, Mike Simpkins for very helpful reviews of this document, staff at the NMFS's Northeast Regional Office for their cooperation and reviews of this document, NMFS observers for field data collection, Sara Weeks for providing pinger tester data, Northeast Fisheries Science Center Protected Species Division staff for much of the work cited in this document, and several anonymous reviewers who greatly improved this manuscript.

\section{LITERATURE CITED}

Allen LK, Rossman MC, Bisack KD, Palka DL (1999) Implementation of bycatch reduction schemes for incidental catch of harbor porpoises in the U.S. Gulf of Maine multispecies sink gillnet fishery. SC/51/SM18, International Whaling Commission, Cambridge

> Barlow J, Cameron GA (2003) Field experiments show that acoustic pingers reduce marine mammal bycatch in the California drift gill net fishery. Mar Mamm Sci 19: 265-283

Berggren P, Wade PR, Carlstrom J, Read AJ (2002) Potential limits to anthropogenic mortality for harbour porpoises in the Baltic region. Biol Conserv 103:313-322

Collins JW (1886) Gill-nets in the cod fishery: a description of Norwegian cod-nets, etc., and a history of their use in the United States. Report of the U.S. Fisheries Commission for 1884, Washington, DC, Part XII: 265-285

CONCUR (2008a) Key outcomes memorandum, harbor porpoise take reduction team, Philadelphia, PA, 17-19 Dec 2007. Available at www.nero.noaa.gov/prot_res/ porptrp/MeetingsKeyOutcomes.html (accessed 30 April 2013)

CONCUR (2008b) Key outcomes memorandum, harbor porpoise take reduction team 31 Jan 2008. Available at www. nero.noaa.gov/prot_res/porptrp/MeetingsKeyOutcomes .html (accessed 30 April 2013)

Dawson SM, Northridge S, Waples D, Read AJ (2013) To ping or not to ping: the use of active acoustic devices in mitigating interactions between small cetaceans and gillnet fisheries. Endang Species Res 19:201-221

DFO (Department of Fisheries and Oceans) (1998) Harbour porpoise bycatch in the lower Bay of Fundy gillnet fishery. DFO Maritimes Regional Fisheries Status Report 98/7E. Available from: DFO, Resource Management Branch, Halifax, Canada

Gaskin DE (1984) The harbour porpoise Phocoena phocoena (L.): regional populations, status, and information on direct and indirect catches. Rep Int Whal Comm 34: 569-586

> Haring P, Maguire JJ (2008) The monkfish fishery and its management in the northeastern USA. ICES J Mar Sci 65:1370-1379

International Whaling Commission (2000) Report of the Scientific Committee, Annex I. Report of the sub-committee on small cetaceans. J Cetacean Res Manag 2(Suppl): $235-257$

Jefferson TA, Curry BE (1994) A global review of porpoise (Cetacea: Phocoenidae) mortality in gillnets. Biol Conserv 67:167-183

> Kraus SD, Read AJ, Solow A, Baldwin K, Spradlin T, Anderson E, Williamson J (1997) Acoustic alarms reduce porpoise mortality. Nature 388:525

Mediation Institute (2000a) Mid-Atlantic Harbor Porpoise Take Reduction Team, final meeting summary and Take Reduction Team recommendations. Available at: www. nero.noaa.gov/prot_res/porptrp/masummary2000.pdf (accessed 30 April 2013) 
Mediation Institute (2000b) Gulf of Maine Take Reduction Team, final meeting summary and Take Reduction Team recommendations. Available at: www.nero.noaa.gov/ prot_res/porptrp/gomsum2000.pdf (accessed 30 April 2013)

Murawski SA, Wigley SE, Fogarty MJ, Rago PJ, Mountain DG (2005) Effort distribution and catch patterns adjacent to temperate MPAs. ICES J Mar Sci 62:1150-1167

Murray KT, Read AJ, Solow AR (2000) The use of time-area closures to reduce by-catches of harbour porpoises: lessons from the Gulf of Maine sink gillnet fishery. J Cetacean Res Manag 2:135-141

NEFMC \& MAFMC (New England Fishery Management Council and Mid-Atlantic Fishery Management Council (2011) Monkfish Fishery Management Plan Framework Adjustment 7: incorporating Stock Assessment and Fishery Evaluation (SAFE) report for the 2009 fishing year and the environmental assessment, published in consultation with NOAA National Marine Fisheries Service (NMFS). Available at http://docs.lib.noaa.gov/noaa documents/PPI/NEPA/FY2011/110915_EA_Monkfish_ FW7_L.pdf (accessed 30 April 2013)

NMFS (National Marine Fisheries Service) (1991) Endangered and threatened species. Review of the status of harbor porpoise. Fed Regist 56:65044-65045

NMFS (National Marine Fisheries Service) (2007) Harbor Porpoise Take Reduction Team meeting materials. Available from Northeast Fisheries Science Center, NOAA, Woods Hole, MA

NOAA Fisheries (2010) Harbor porpoise take reduction plan monitoring strategy: monitoring the effectiveness and regulatory compliance of the harbor porpoise take reduction plan (HPTRP). Available at: www.nero.noaa.gov/prot _res/porptrp/doc/HPTRP\%20Monitoring\%20Summary \%204-2-2010.pdf (accessed 30 April 2013)

Northeast Fisheries Observer Program (NEFOP) (2013) Observer program manual. Available at http://www.nefsc. noaa.gov/fsb/manuals/2013/NEFSC_Observer_Program_ Manual.pdf (accessed 30 April 2013)

Orphanides CD (2009) Protected species bycatch estimating approaches: estimating harbor porpoise bycatch in the U.S. northwestern Atlantic gillnet fisheries. J Northwest Atl Fish Sci 42:55-76

Orphanides CD (2010) Update on Harbor Porpoise Take Reduction Plan monitoring initiatives: compliance and consequential bycatch rates from June 2008 through May 2009. Reference Document 10-22, Northeast Fisheries Science Center, NOAA, Woods Hole, MA. Available at www.nefsc.noaa.gov/nefsc/publications/ crd/crd1022/ (accessed 30 April 2013)

Orphanides CD (2011a) Estimates of cetacean and pinniped bycatch in the 2009 New England sink gillnet and mid-Atlantic gillnet fisheries. Reference Document 11-08, Northeast Fisheries Science Center, NOAA, Woods Hole, MA. Available at www.nefsc.noaa.gov/ nefsc/publications/crd/crd1108/index.html (accessed 30 April 2013)

Orphanides CD (2011b) An examination of the impact of time-area closures on harbor porpoise bycatch in the US northwestern Atlantic gillnet fishery. Consortium for Wildlife Bycatch Reduction Workshop, Falmouth, MA. October 2011. http://bycatch.org/sites/default/files/ Abstracts.pdf (accessed 30 April 2013)

Orphanides CD (2012) Update on Harbor Porpoise Take Reduction Plan monitoring initiatives: compliance and consequential bycatch rates from June 2009 through May 2010. Reference Document 12-22, Northeast Fisheries Science Center, NOAA, Woods Hole, MA. Available at www.nefsc.noaa.gov/nefsc/publications/crd/ crd1222/ (accessed 30 April 2013)

Orphanides CD, Magnusson GM (2007) Characterization of the Northeast and mid-Atlantic bottom and mid-water trawl fisheries based on Vessel Trip Report (VTR) data. Reference Document 07-15, Northeast Fisheries Science Center, NOAA, Woods Hole, MA. Available at www. nefsc.noaa.gov/nefsc/publications/crd/crd0715/ (accessed 30 April 2013)

Orphanides CD, Palka DL (2008) Bycatch of harbor porpoises in three U.S. gillnet management areas: Southern Mid-Atlantic, Offshore, and Western Gulf of Maine. Reference Document 08-09, Northeast Fisheries Science Center, NOAA, Woods Hole, MA. Available at http:// www.nefsc.noaa.gov/nefsc/publications/crd/crd0809/ (accessed 27 April 2013)

Orphanides CD, Palka D (2012) 2010-2011 HPTRP consequential bycatch and compliance rates. Reference Document 12-08, Northeast Fisheries Science Center, NOAA, Woods Hole, MA. Available at: www.nefsc.noaa.gov/ nefsc/publications/crd/crd1208 (accessed 30 April 2013)

Orphanides CD, Wetmore S, Johnson A (2009) Update on Harbor Porpoise Take Reduction Plan monitoring initiatives: compliance and consequential bycatch rates from June 2007 through May 2008, pinger tester development and enforcement from January 2008 through July of 2009. Reference Document 09-14, Northeast Fisheries Science Center, NOAA, Woods Hole, MA. Available at www. nefsc.noaa.gov/publications/crd/crd0914/ (accessed 30 April 2013)

Palka DL, Rossman MC, VanAtten AS, Orphanides CD (2008) Effect of pingers on harbour porpoise bycatch in the US northeast gillnet fishery. J Cetacean Res Manag 10:217-226

Palka D, Orphanides CD, Warden ML (2009) Summary of harbor porpoise (Phocoena phocoena) bycatch and levels of compliance in the northeast and mid-Atlantic gillnet fisheries after the implementation of the Take Reduction Plan: 1 January 1999-31 May 2007. NOAA Tech Memo NMFS NE 212, Northeast Fisheries Science Center, NOAA, Woods Hole, MA. Available at www. nefsc.noaa.gov/nefsc/publications/tm/tm212/ (accessed 30 April 2013)

Rago PJ, Sosebee KA (2010) Biological reference points for spiny dogfish. Reference Document 10-06, Northeast Fisheries Science Center, NOAA, Woods Hole, MA. Available at http://nefsc.noaa.gov/publications/crd/ crd1006/ (accessed 30 April 2013)

Read AJ (2013) Development of conservation strategies used to mitigate the bycatch of harbor porpoises in the Gulf of Maine. Endang Species Res 20:235-250

> Read AJ, Westgate AJ (1997) Monitoring the movements of harbour porpoises (Phocoena phocoena) with satellite telemetry. Mar Biol 130:315-322

Rossman MC (2000) Effectiveness of time-area closures and acoustic deterrents as harbor porpoise bycatch reduction strategies off the northeast coast of the United States. SC/52/SM23, International Whaling Commission, Cambridge

> Tregenza NJC, Berrow SD, Hammond PS, Leaper R (1997) Harbour porpoise (Phocoena phocoena L.) by-catch in set gillnets in the Celtic Sea. ICES J Mar Sci 54:896-904 
Trippel EA, Wang JY, Strong MB, Carter LS, Conway JD (1996) Incidental mortality of harbour porpoise (Phocoena phocoena) by the gill-net fishery in the lower Bay of Fundy. Can J Fish Aquat Sci 53:1294-1300

Trippel EA, Strong MB, Terhune JM, Conway JD (1999) Mitigation of harbour porpoise (Phocoena phocoena) bycatch in the lower Bay of Fundy. Can J Fish Aquat Sci 56: 113-123

Vinther M, Larsen F (2004) Updated estimates of harbour porpoise by-catch in the Danish bottom set gillnet fishery. J Cetacean Res Manag 6:19-24

Waring GT, Palka DL, Mullin KD, Hain JHW, Hansen LJ, Bisack KD (1997) US Atlantic and Gulf of Mexico Marine Mammal Stock Assessments - 1996. NOAA Tech Memo NMFS NE 114, Northeast Fisheries Science Center, NOAA, Woods Hole, MA. Available at www.nefsc.noaa. gov/nefsc/publications/tm/tm114/ (accessed 30 April 2013)

Waring GT, Quintal JM, Swartz SL (eds) (2000) US Atlantic and Gulf of Mexico marine mammal stock assessments 2000. NOAA Tech Memo NMFS NE 162, Northeast Fisheries Science Center, NOAA, Woods Hole, MA. Available at www.nefsc.noaa.gov/nefsc/publications/tm/tm162/ (accessed 30 April 2013)

Waring GT, Quintal JM, Schwartz SL (eds) (2001) US Atlantic and Gulf of Mexico marine mammal stock assessments - 2001. NOAA Tech Memo NMFS NE 168, Northeast Fisheries Science Center, NOAA, Woods Hole,

Editorial responsibility: Andrew Read, Beaufort, North Carolina, USA
MA. Available at www.nefsc.noaa.gov/nefsc/publications/ tm/tm168/ (accessed 30 April 2013)

Waring GT, Josephson E, Fairfield CP, Maze-Foley K (eds) (2007a) US Atlantic and Gulf of Mexico marine mammal stock assessments - 2006. NOAA Tech Memo NMFS NE 201, Northeast Fisheries Science Center, NOAA, Woods Hole, MA. Available at www.nefsc.noaa.gov/nefsc/ publications/tm/tm201/ (accessed 30 April 2013)

Waring GT, Josephson E, Fairfield-Walsh CP, Maze-Foley K (eds) (2007b) US Atlantic and Gulf of Mexico Marine Mammal Stock Assessments - 2007. NOAA Tech Memo NMFS NE 205, Northeast Fisheries Science Center, NOAA, Woods Hole, MA. Available at www.nefsc.noaa. gov/nefsc/publications/tm/tm205/ (accessed 30 April 2013)

Waring GT, Josephson E, Fairfield-Walsh CP, Maze-Foley K (eds) (2009) US Atlantic and Gulf of Mexico Marine Mammal Stock Assessments - 2008. NOAA Tech Memo NMFS NE 210. Northeast Fisheries Science Center, NOAA, Woods Hole, MA. Available at www.nefsc.noaa. gov/nefsc/publications/tm/tm210/

Waring GT, Josephson E, Maze-Foley K, Rosel PE (eds) (2011) US Atlantic and Gulf of Mexico marine mammal stock assessments - 2010. NOAA Tech Memo NMFS NE 219, Northeast Fisheries Science Center, NOAA, Woods Hole, MA. Available at www.nefsc. noaa.gov/nefsc/publications/tm/tm219/ (accessed 30 April 2013)

Submitted: July 3, 2012; Accepted: January 26, 2013 Proofs received from author(s): May 1, 2013 